\title{
Herbicidal potential of Araucaria angustifolia (Bertoloni) Otto Kuntze in lettuce seedlings in vitro
}

Nayara Clarete da Penha ${ }^{1}$

Priscila Pereira Botrel ${ }^{2}$

Jéssica Azevedo Batista ${ }^{3}$

\section{Abstract}

Araucaria angustifolia (Bertoloni) Otto Kuntze plants are a viable source of potentially active secondary metabolites; however, deep studies and researches about the activity of these compounds are needed. The objective of this work was to assess the herbicidal activity of ethanolic extracts of plants of the species $A$. angustifolia in lettuce seedlings in vitro. Ethanolic extracts at different concentrations $(0,0 \%, 12.5 \%, 25.0 \%, 50.0 \%$, and $100.0 \%)$ were prepared using barks and leaves. A semisolid MS medium with $\mathrm{pH}$ adjusted to approximately 5.7 was prepared, solidified with $8 \mathrm{~g} \mathrm{~L}^{-1}$ of agar, and autoclaved at 1.6atm for 20 minutes. The extracts were added to the culture medium during their preparation before the autoclaving, using an automatic pipette containing $0.1 \mathrm{~mL}$ of $A$. angustifolia extract per lettuce seedling. The number of leaves per seedling, seedling height, chlorophyll content, root and shoot dry weights, and mortality percentage was determined at 20 days after inoculation. The results showed that the extract from leaves or barks of $A$. angustifolia plants has herbicidal activity in lettuce seedlings in vitro, and the extract concentration of $100 \%$ presented the best inhibitory results for the variables evaluated.

Keywords: Biological activity. Araucaria. In vitro culture. Plant mortality. Lactuca sativa L.

\section{Introduction}

Araucaria angustifolia (Bertoloni) Otto Kuntze is a typical Brazilian coniferous tree species; its trees are large and have perennial leaves and straight and almost cylindrical trunks (AQUINO, 2005). Taxonomically, A. angustifolia belongs to the Coniferae order, Coniferopsida class, and Araucariaceae family, and it is popularly known as Brazilian pine or Parana pine (ANGELI; STAPE, 2003).

This species is a viable source of potentially active secondary metabolites; however, deep studies and researches about the activity of these compounds are needed (ALMEIDA, 2003).

Distilled Araucaria angustifolia (Bertoloni) Otto Kuntze compounds present some pharmacological activities, such as anticancer, antimicrobial, antifungal, and antiviral (LIN et al., 1999; GRYNBERG et al., 2002). According to Lucho et al. (2009), ethanolic extracts of $A$. angustifolia present insecticide potential against Leurolestes circunvagans.

According to Seccon et al. (2010), the barks of $A$. angustifolia trees have high concentration of flavonoids, and their leaves contain proanthocyanidins (FREITAS et al., 2009). The resin of these trees

1 Universidade Federal de Alfenas (UNIFAL), mestranda em Ciências Ambientais. nayara.clarete.p@gmail.com. Rua Gabriel Monteiro da Silva, 700, Alfenas-MG, 37130-001.

2 IFSULDEMINAS, Campus Muzambinho. Professora. botrelpp@gmail.com.

3 IFSULDEMINAS, Campus Muzambinho. Laboratorista. batistaja7@gmail.com. 
contains phenolic acids, hydroquinone, and ferruginol (YAMAMOTO et al., 2004 apud SOUZA, 2013). Approximately $50 \%$ of the resin of some coniferous plants is composed of resin acids, $20 \%$ to $30 \%$ is volatile monoterpenes, and part of it is composed of terpenoid and fat acid esters (KLOCK; ANDRADE, 2013). In addition, A. angustifolia trees contain several terpenoids (germacrene-D, diterpenes, and phyllocladene), termed araucaroids, which are present in the volatile oil of their leaves (BROPHY et al., 2000 apud RAMOS; BORTOLUZZI; MANTOVANI, 2010).

Weed management is important to achieve high yields of agricultural crops. The losses can be significant, depending on the species, density, and distribution of the weeds, mainly due to competition for solar radiation, water, and nutrients, hindering the harvest and quality of agricultural products (EMBRAPA, 2003).

The discovery of natural herbicides enables the formulation of efficient products that can be less persistent in the environment and present lower toxicity than molecules of chemical products. In addition, natural herbicides can decrease natural selection of resistant or tolerant plant biotypes, which cause crop yield losses. These resistances are usually caused by the continuous use of a single herbicide (EMBRAPA, 2014).

Considering the substances already identified in the different parts of $A$. angustifolia plants and their biological potential, and the importance of discovering new herbicidal molecules, the objective of this work was to assess the herbicidal activity of ethanolic extracts of plants of the species A. angustifolia in lettuce seedlings in vitro. Despite some studies found in the literature report the use of A. angustifolia plants for growth inhibition of lettuce plants, these researches are divergent in relation to the part of the plant to be used and are not conclusive, mainly because they use ex vitro tests.

\section{Material and methods}

\section{Location of the experiment and preparation of extracts of $A$. angustifolia}

The experiment was conducted in May 2017 at the Laboratory of Biotechnology/Plant Tissue Culture of the Federal Institute of Education, Science, and Technology of South of Minas Gerais (IFSULDEMINAS), in Muzambinho, MG, Brazil.

Leaves and barks of $A$. angustifolia plants were collected from adult plants in Muzambinho, in the morning period, at 8:00 a.m., focused on a standardization of the collection time, since this factor can affect the chemical composition of the plant part. The extracts were obtained from plants dried in a forced-air circulation oven at $40{ }^{\circ} \mathrm{C}$ for 72 hours. The dried plant parts were then ground in a knife Willey mill, dissolved in ethylic alcohol, and stored in the dark in a refrigerator for 12 hours.

All extracts were prepared using 100 grams of the plant part for each $900 \mathrm{~mL}$ of ethylic alcohol, corresponding to the gross extract, concentration of $100 \%$. The extracts were filtrated to remove large particles and, then, diluted to obtain the concentrated solutions of $12.5 \%, 25.0 \%, 50.0 \%$, and $100.0 \%$. The effect of these concentrations was compared to the effect of distilled water (control treatment).

\section{Preparation of the culture medium and procedures for in vitro culture of lettuce seeds}

A semisolid MS medium (MURASHIGE; SKOOG, 1962) with pH adjusted to approximately 5.7 was prepared, solidified with $8 \mathrm{~g} \mathrm{~L}^{-1}$ of agar, and autoclaved at $1.6 \mathrm{~atm}$ for 20 minutes. The extracts were added to the culture medium during their preparation before the autoclaving, using an automatic 
pipette containing $0.1 \mathrm{~mL}$ of the $A$. angustifolia extract per in vitro lettuce seedling, totaling $2.0 \mathrm{~mL}$ of extract for each treatment.

Two hundred lettuce seeds of the commercial cultivar Regina were used. The asepsis of these seeds was carried out using $1.25 \%$ active chloride for 15 minutes, followed by washing of the seeds four times with distilled autoclaved water in a laminar flow cabinet.

The lettuce seeds were inoculated in bottles containing $40 \mathrm{~mL}$ of culture medium. Each bottle contained five seeds; after inoculation, they were kept in a BOD chamber under photoperiod of 16 hours and temperature of $25^{\circ} \mathrm{C}$.

\section{Experimental design and statistical analysis}

A completely randomized experimental design was used, in a $2 \times 5$ factorial arrangement (leaves and barks $\times$ concentrations of ethanolic extract), totaling 10 treatments, with four replications, using five plants per plot.

The shoot and root dry weights, seedling height $(\mathrm{cm})$, number of leaves, chlorophyll content, and mortality percentage were evaluated at 20 days of in vitro culture. Chlorophyll content was measured using a Clorofilog device. The statistical analyses were carried out using the Sisvar program (FERREIRA, 2011) with fitting of regression for the ethanolic extract concentrations as a function of the different plant parts (leaves and barks) of $A$. angustifolia.

\section{Results and discussion}

The interaction between plant parts (barks and leaves) of $A$. angustifolia and the different ethanolic extract concentrations was not significant for number of leaves and chlorophyll content, but it was significant for the lettuce seedling height. Significant difference was not found for the variables of the lettuce seedlings, considering the analysis of variance for the plant parts; whereas the concentrations of the extracts of these plant parts affected the number of leaves, seedling height, and chlorophyll content (TABLE 1).

Table 1 - Mean square and coefficient of variation of residues for number of leaves, seedling height, and chlorophyll content in lettuce seedlings as a function of plant parts, extract concentrations, and their interaction. IFSULDEMINAS, Muzambinho/MG, Brazil, 2018.

\begin{tabular}{lcccc}
\hline \multirow{2}{*}{ Source of variation } & \multicolumn{4}{c}{ Mean square } \\
\cline { 2 - 5 } & DF & Number of leaves & Seedling height (cm) & Chlorophyll content \\
\hline Plant parts (PP) & 1 & $6.480000^{\text {ns }}$ & $0.393384^{\text {ns }}$ & $3.892050^{\text {ns }}$ \\
Extract concentrations (EC) & 4 & $130.192500^{*}$ & $78.017884^{*}$ & $425.025750^{*}$ \\
PP $\times$ EC & 4 & $3.192500^{\text {ns }}$ & $5.492234^{*}$ & $33.153800^{\text {ns }}$ \\
Error & 190 & 2.085263 & 0.866725 & 31.536466 \\
Coefficient of variation (\%) & & 45.55 & 51.13 & 89.60 \\
\hline
\end{tabular}

$\mathrm{DF}=$ degrees of freedom; ${ }^{\mathrm{ns}}=$ not significant; ${ }^{*}=$ significant by the analysis of variance at $5 \%$ probability level.

Fonte: Elaborated by the authors (2018).

The number of leaves of the lettuce seedling decreased linearly as the extract concentration increased. The extract concentration of $25 \%$ presented the second highest number of leaves, after the 
control, in which only distilled water was used. The extract concentration of $100 \%$ showed the best results, with the lowest number of leaves per plot, differing from the other concentrations (Figure 1 ).

Figure 1 - Mean number of leaves in lettuce seedlings as a function of treatments with different extract concentrations of $A$. angustifolia plants, IFSULDEMINAS, Muzambinho/MG, Brazil, 2018.

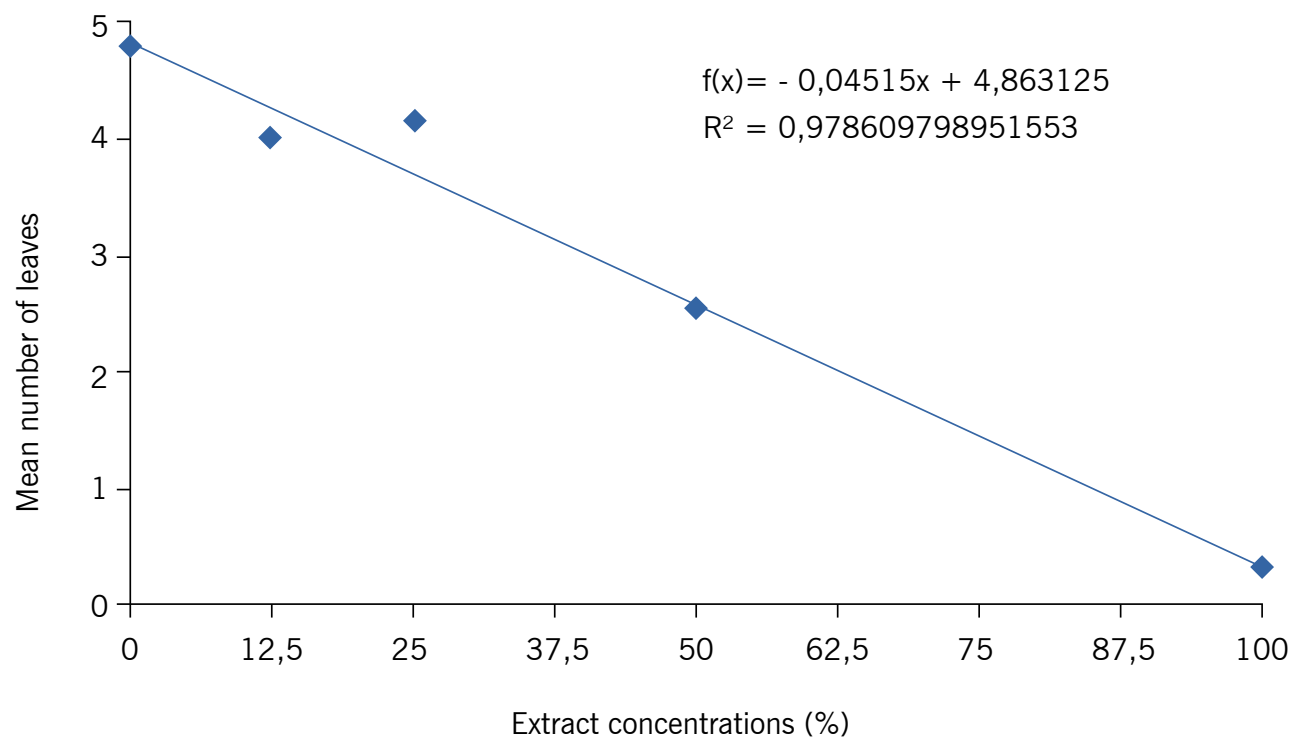

Fonte: Elaborated by the authors (2018).

According to Silveira et al. (2014), aqueous extracts from leaves of $A$. angustifolia plants have inhibitory effects on germination rate, germination speed, and initial growth of lettuce (Lactuca sativa L.), which are similar to the results found in the present work.

Figure 2 shows that the mean seedling height tends to decrease as the concentration of the extract from the barks of $A$. angustifolia plants is increased. The lowest lettuce seedling height was found for the estimated extract concentration of $80.7 \%$.

Figure 2 - Mean lettuce seedling heights as a function of treatments with different extract concentrations of A. angustifolia plants using their barks. IFSULDEMINAS, Muzambinho/MG, Brazil, 2018.

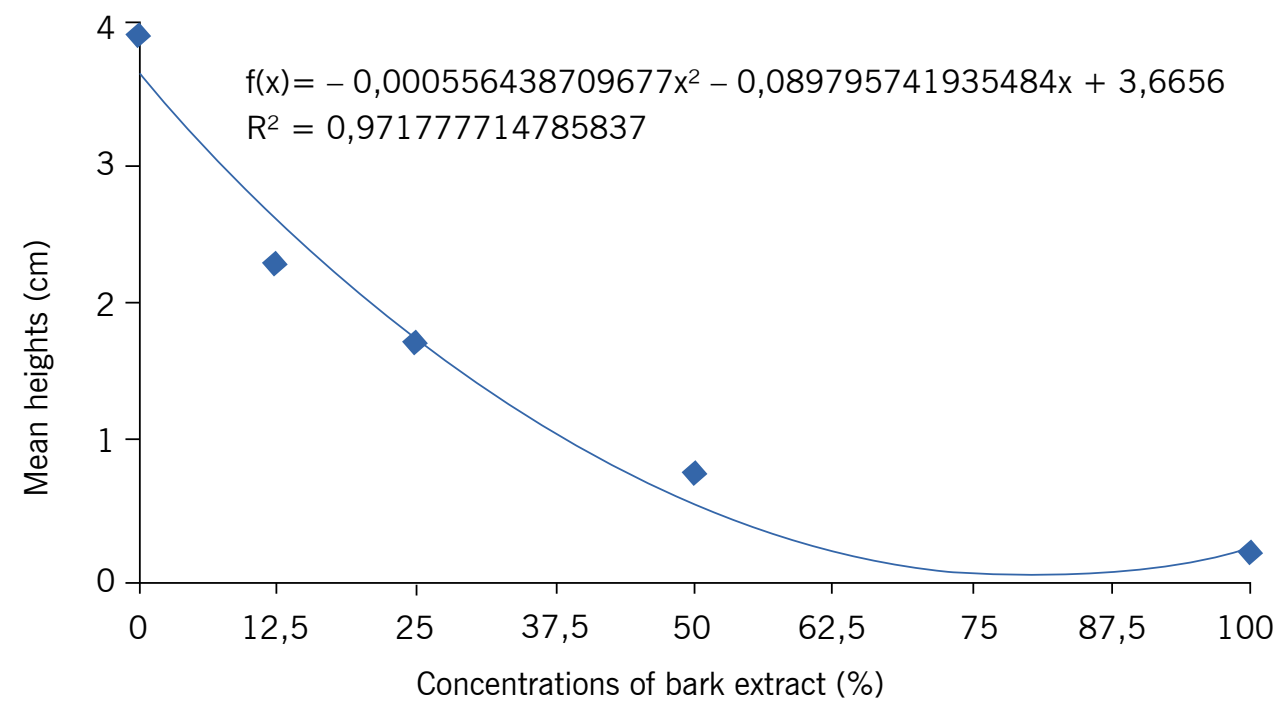

Fonte: Elaborated by the authors (2018). 
According to Klein et al. (2017), the aqueous extract from peels of fruits of $A$. angustifolia can efficiently inhibit seed germination in lettuce (Lactuca sativa L.), denoting its natural herbicidal potential.

The chlorophyll content means fitted to a quadratic model. The highest chlorophyll content (8.13\%) was found when using the estimated concentration of $22.27 \%$ of the $A$. angustifolia extract. The concentration 100\% resulted in the lowest chlorophyll content (Figure 3).

Figure 3 - Mean chlorophyll content in lettuce seedlings as a function of treatments with different extract concentrations of $A$. angustifolia plants, IFSULDEMINAS, Muzambinho/MG, Brazil, 2018.

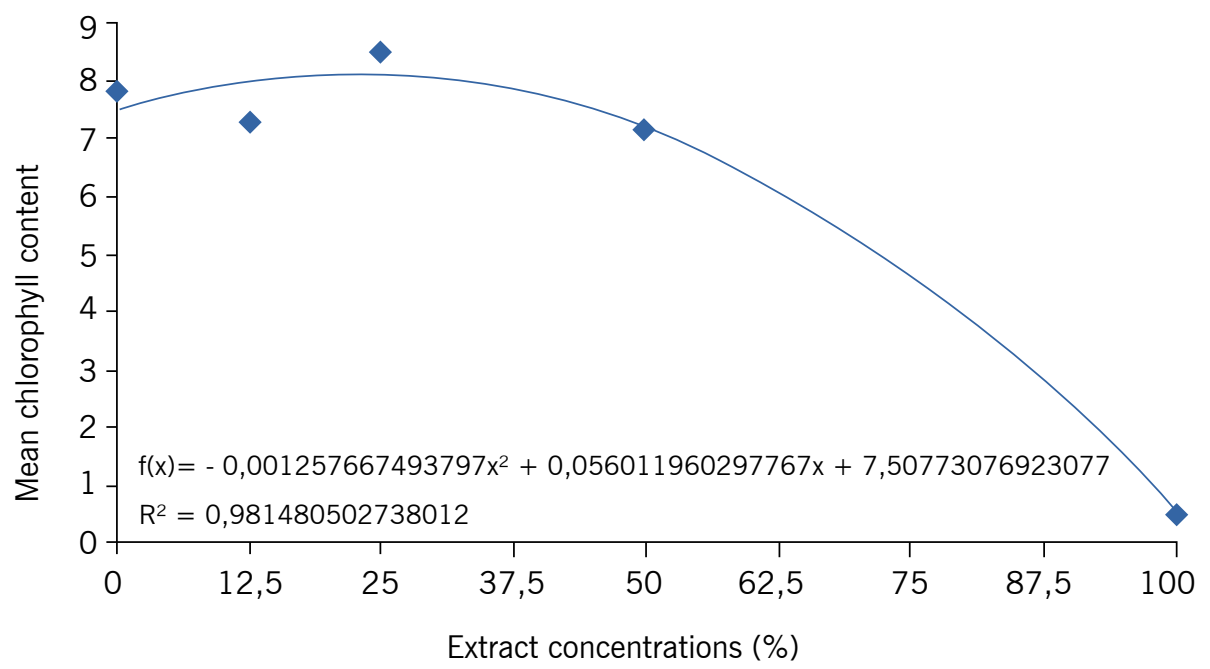

Fonte: Elaborated by the authors (2018).

Chlorophyll and carotenoid contents in leaves indicate the damage level that a stress cause to the plant; chlorosis is usually a first symptom (CATUNDA et al., 2005). Hendry et al. (1987 cited by CATUNDA et al., 2005) report that stress situations caused by herbicides destroy chlorophylls with higher intensity than carotenoids; thus, the ratio between chlorophyll and carotenoid concentration can be used as a factor to evaluate damages to plants.

The interaction between plant parts (barks and leaves) of $A$. angustifolia and different extract concentrations was not significant for mean shoot dry weight, mean root dry weight, and mean mortality percentage. Differences for these variables as a function of plant parts (barks and leaves) of $A$. angustifolia were not found through the analysis of variance. However, the concentrations of their extracts affected significantly all these variables (Table 2).

Table 2 - Mean square and coefficient of variation of residues for shoot dry weight (SDW), root dry weight (RDW) and mortality percentage (MP) of lettuce seedlings as a function of plant parts, extract concentrations, and their interaction, IFSULDEMINAS, Muzambinho/MG, Brazil, 2018.

\begin{tabular}{lcccc}
\hline \multirow{2}{*}{ Source of variation } & \multicolumn{4}{c}{ Mean square } \\
\cline { 2 - 5 } & DF & SDW & RDW & MP \\
\hline Plant parts (PP) & 1 & $0.000004^{\text {ns }}$ & $1.9600000 \mathrm{E}-0007^{\text {ns }}$ & $360.0^{\text {ns }}$ \\
Extract concentrations (EC) & 4 & $0.000043^{*}$ & $0.000005^{*}$ & $9050.0^{*}$ \\
PP $\times$ EC & 4 & $0.000004^{\text {ns }}$ & $0.000001^{\text {ns }}$ & $110.0^{\text {ns }}$ \\
\hline & & & & (continue $\ldots$ )
\end{tabular}


(continue...)

Table 2 - Continuation

\begin{tabular}{lcccc}
\hline \multirow{2}{*}{ Source of variation } & \multicolumn{4}{c}{ Mean square } \\
\cline { 2 - 5 } & DF & SDW & RDW & MP \\
\hline Error & 30 & 0.000002 & 0.000001 & 413.333333 \\
Coefficient of variation (\%) & & 28.65 & 80.23 & 81.32 \\
\hline
\end{tabular}

$\mathrm{DF}=$ degrees of freedom; ns $=$ not significant; ${ }^{*}=$ significant by the analysis of variance at $5 \%$ probability level.

Fonte: Elaborated by the authors (2018).

The lowest shoot dry weight of lettuce seedlings was found for the extract concentration of $100 \%$. The shoot dry weight tended to decrease (quadratic model) as the extract concentration was increased (Figure 4).

Figure 4 - Mean shoot dry weight of lettuce seedlings $(\mathrm{mg})$ as a function of treatments with different extract concentrations of $A$. angustifolia plants, IFSULDEMINAS, Muzambinho/MG, Brazil, 2018.

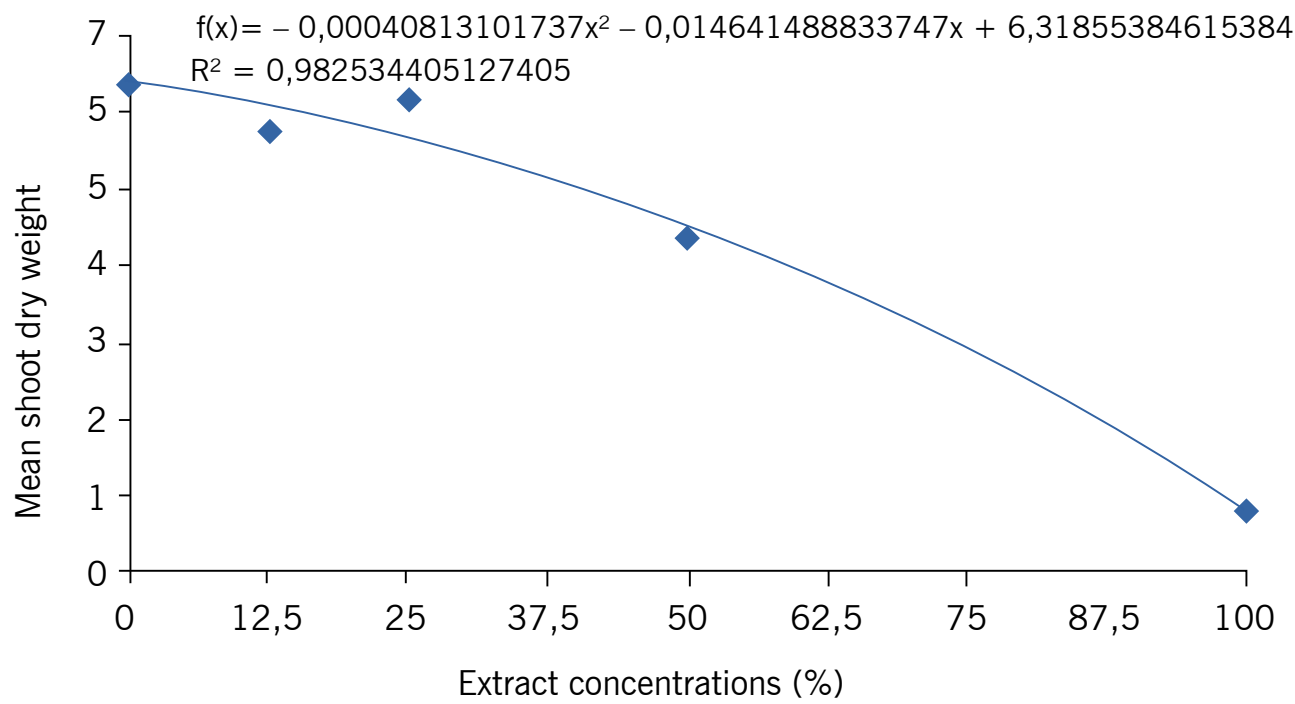

Fonte: Elaborated by the authors (2018).

The lowest root dry weight was found for the extract concentration of $100 \%$, with mean root dry weight near zero, lower than that of the seedlings in the control treatment (Figure 5). 
Figure 5 - Mean root dry weight of lettuce seedlings $(\mathrm{mg})$ as a function of treatments with different extract concentrations of $A$. angustifolia plants, IFSULDEMINAS, Muzambinho/MG, Brazil, 2018.

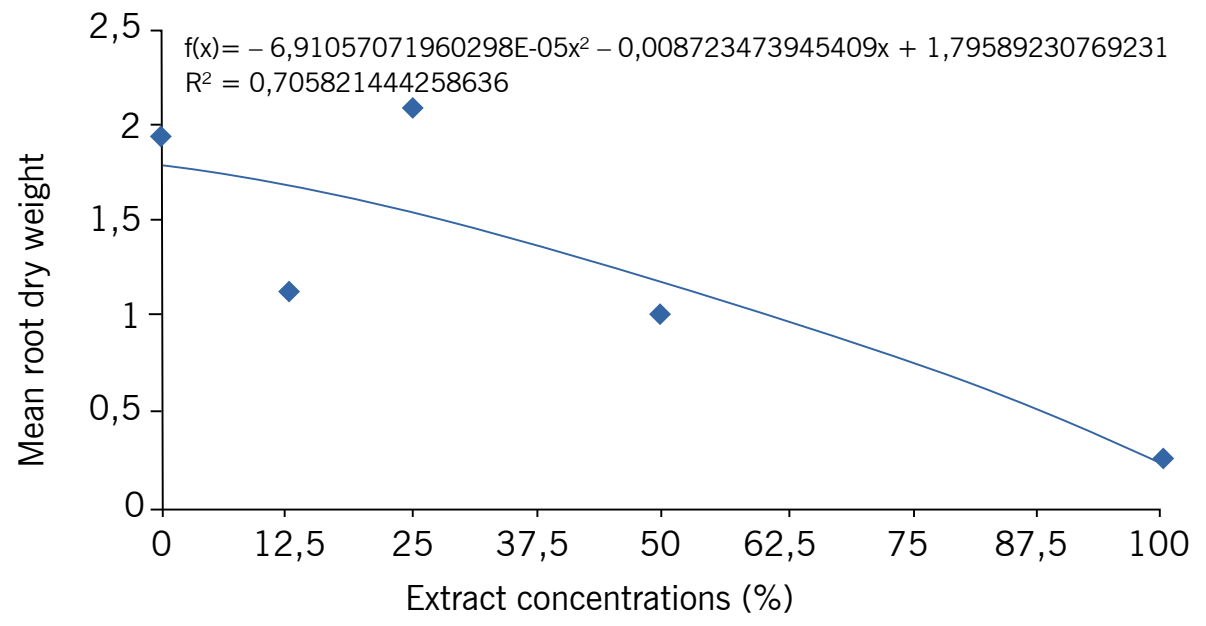

Fonte: Elaborated by the authors (2018).

Braine et al. (2011) also found inhibitory effects of substances found in A. angustifolia plants on lettuce plants when testing the contact of whole and powdered senesced aciculae with the lettuce seeds, and they pointed out that the aciculae decreased the seed germination speed and affected the root system size of the plants.

The highest mortality percentage of lettuce seedlings was found for the extract concentration of $100 \%$ (FIGURE 6). The means fitted to the quadratic model, with an increasing mortality percentage of lettuce seedlings as the extract concentration was increased. The lowest mortality percentage $(0.89 \%)$ was found for the estimated extract concentration of $11.79 \%$.

Figure 6 - Mean mortality percentage of lettuce seedlings as a function of treatments with different extract concentrations of $A$. angustifolia plants, IFSULDEMINAS, Muzambinho/MG, Brazil, 2018.

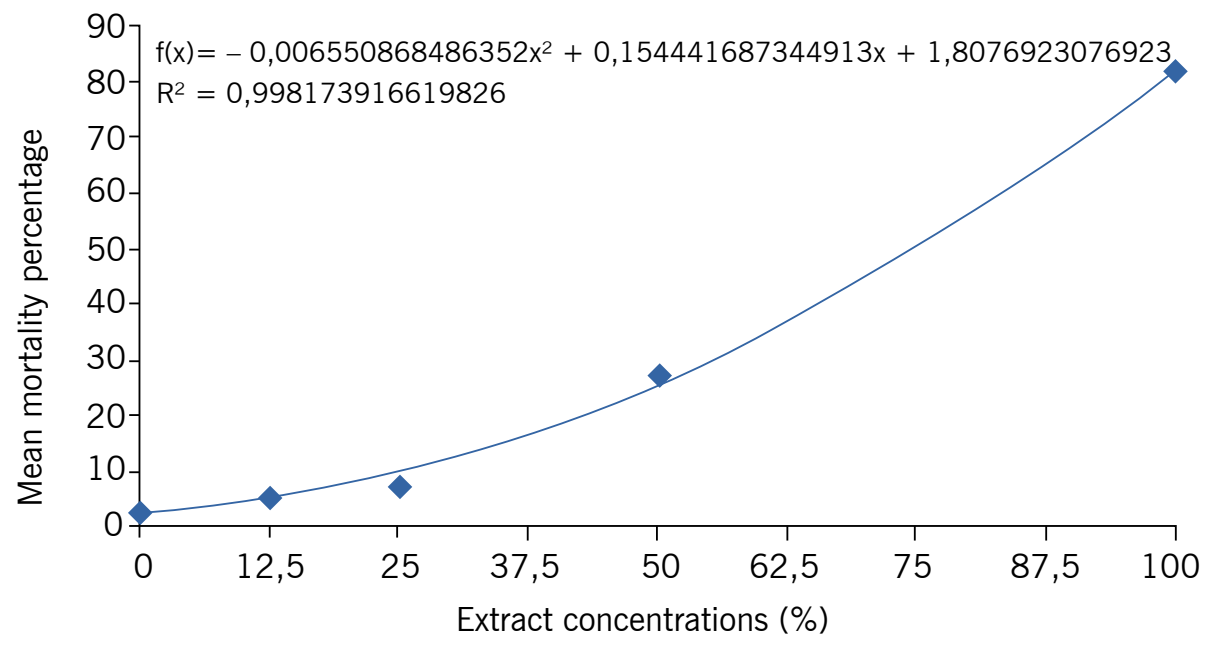

Fonte: Elaborated by the authors (2018).

The inhibitory effects of the $A$. angustifolia on the development of other plant species is probably due to the presence of catechin, which is a chemical compound found in aqueous extract of bract 
plants (MICHELON et al., 2012 apud SOUZA, 2013). Taiz et al. (2017) reported that catechin is an allelopathic phytotoxic secondary metabolite that inhibits root growth of other plants.

\section{Conclusions}

The ethanolic extracts of barks and leaves of plants of the species Araucaria angustifolia present herbicidal activity in lettuce seedlings in vitro; they decreased shoot and root dry weights, plant growth, number of leaves, and chlorophyll content, and increased mortality percentage after they were applied to the lettuce seedlings.

The A. angustifolia extract concentration of $100 \%$ presented the best inhibitory effects, considering the variables evaluated.

\section{Acknowledgements}

The authors thank the Minas Gerais State Agency for Research and Development (FAPEMIG), for granting scientific initiation scholarships and financial support for this project; and the Federal Institute of Education, Science, and Technology of South of Minas Gerais (IFSULDEMINAS), Muzambinho campus, for providing the infrastructure for the experiments.

\section{Avaliação do potencial herbicida de Araucaria angustifolia (Bertoloni) Otto Kuntze in vitro em plântulas de alface}

\section{Resumo}

A Araucaria angustifolia (Bert.) O. Kuntze é uma fonte viável para a obtenção de metabólitos secundários que são potencialmente ativos, o que justifica o aprofundamento de estudos e pesquisas de atividades relacionadas a esses compostos. Este trabalho foi desenvolvido com o objetivo de verificar a atividade herbicida de extratos etanólicos da espécie $A$. angustifolia em plântulas de alface cultivadas in vitro. Os extratos etanólicos foram preparados utilizando cascas e folhas nas concentrações 0\%, 12\%, 5\%, 25\%, 50\% e 100\%. Preparou-se o meio MS semissólido (MURASHIGE; SKOOG, 1962), o qual teve o pH ajustado para aproximadamente 5,7 e foi solidificado com $8 \mathrm{~g} \mathrm{~L}^{-1}$ de ágar e autoclavado a 1,6atm por 20 minutos. A adição das concentrações dos extratos no meio de cultura foi realizada durante sua confecção e antes da autoclavagem, por meio de uma pipeta automática, contendo o volume final de $0,1 \mathrm{~mL}$ de extrato de $A$. angustifolia por plântula de alface. Após 20 dias da inoculação, determinou-se o número de folhas por plântulas, altura, teor de clorofila, biomassa seca da raiz e parte aérea e porcentagem de mortalidade. Os resultados demonstraram que tanto o extrato das folhas quanto o de cascas de $A$. angustifolia possuem atividade herbicida em plântulas de alface cultivadas in vitro e que a concentração $100 \%$ dos extratos foi a que apresentou os melhores resultados inibitórios para as variáveis analisadas.

Palavras-chave: Atividade biológica. Araucária. Cultivo in vitro. Mortalidade de plantas. Lactuca sativa L. 


\section{References}

ALMEIDA, M. T. R. Isolamento e identificação de substâncias ativas Araucaria angustifolia (Bert.) O. Kuntze com potencial atividade antiviral. 2003. Disponível em: <https://repositorio.ufsc.br/ handle/123456789/86288 > . Acesso em: 10 nov. 2016.

ANGELI, A.; STAPE, J. L. Araucaria angustifolia (Araucaria). 2003. Disponível em: <http://www.ipef.br/ identificacao/araucaria.angustifolia.asp>. Acesso em: 30 out. 2016.

AQUINO, F. M. Cultivo da Araucaria angustifolia : viabilidade econômico-financeira e alternativas de incentivo. 2005. Disponível em: <http://novosite.fepese.org.br/portaldeeconomia-sc/arquivos/links/ madeira_moveis_papel/2005 Cultivo da araucaria SC.pdf>. Acesso em: 14 nov. 2016.

BRAINE, J. W.; AGUIAR, A. C.; BEDNARZUK, M. H.; WACHOWICZ, C. M. Germinação de sementes de alface na presença de acículas de Araucaria angustifolia (Araucariaceae). Estudos de Biologia, v. 32, n. 76, p. 67-72, 2011. Disponível em: <https://periodicos.pucpr.br/index.php/estudosdebiologia/ article/view/22868/21972>. Acesso em: 14 jul. 2018.

CATUNDA, M. G.; FREITAS, S.P.; OLIVEIRA, J.G.; SILVA, C.M.M. Efeitos de herbicidas na atividade fotossintética e no crescimento de abacaxi (Ananas comossus). Planta daninha, v. 23, n. 1, p. 115-121, 2005.

EMBRAPA. A busca por herbicidas de base natural. 2014. Disponível em: <https://www.embrapa.br/ busca-de-noticias/-/noticia/2219356/the-search-for-natural-based-herbicides>. Acesso em: 15 nov. 2016.

EMBRAPA. Controle das plantas daninhas. 2003. Disponível em: <https://sistemasdeproducao.cnptia. embrapa.br/FontesHTML/Soja/SojaCentralBrasil2003/controle.htm>. Acesso em: 15 nov. 2016.

FERREIRA, D. F. Sisvar: a computer statistical analysis system. Ciência e Agrotecnologia, v. 35, n. 6 , p. 1039-1042, 2011.

FREITAS, A. M.; ALMEIDA, M. T.; ANDRIGHETTI-FRÖHNER, C. R.; CARDOZO, F. T.; BARARDI, C. R.; FARIAS, M. R.; SIMÕES, C. M. Antiviral activity-guided fractionation from Araucaria angustifolia leaves extract. Journal Of Ethnopharmacology, v. 126, p. 512-517, 2009.

GRYNBERG, N. F.; CARVALHO, M. G.; VELANDIA, J. R.; OLIVEIRA, M. C.; MOREIRA, I. C.; BRAZ-FILHO, R.; ECHEVARRIA, A. DNA topoisomerase inhibitors: biflavonoids from Ouratea species. Braz J Med Biol Res, v. 35, n. 7, p. 819-822, 2002. Disponível em: <http://www.scielo.br/scielo. php?script=sci_arttext\&pid=S0100-879X2002000700009 > . Acesso em: 14 nov. 2016.

KLEIN, M. I.; BIONDO, E.; KOLCHINKI, E. M.; SANT'ANNA, V. Efeito alelopático de extrato aquoso de resíduos industriais de noz-pecã [Carya illinoinensis (Wangenh) C. Koch] e de pinhão (Araucaria angustifolia). Revista Eletrônica Científica da UERGS, v. 3, n. 3, p. 495-507, set. 2017.

KLOCK, U.; ANDRADE, A. S. Química da madeira. 2013. Disponível em: <http://www.madeira.ufpr.br/ disciplinasklock/quimicadamadeira/Quimica da Madeira 2013.pdf>. Acesso em: 13 nov. 2016. 
LARCHER, W. Ecofisiologia Vegetal. São Carlos: Rima, 2004. 531p.

LIN, Y.; FLAVIN, M. T.; SCHURE, R.; CHEN, F. C.; SIDWELL, R.; BARNARD, D. L.; HUFFMAN, J. H.; KERN, E. R. Antiviral activities of biflavonoids. Planta Médica, v. 65, n. 2, p.120-125, 1999. Disponível em: <https://www.ncbi.nlm.nih.gov/pubmed/10193201>. Acesso em: 14 nov. 2016.

LUCHO, A. P. B.; PERDOMO JúNIOR, J. D.; SÜRMER, G. D.; BUGS, C. A.; BELO, C. A. D. Avaliação Da Atividade Inseticida do extrato etanólico de Araucária angustifólia em baratas da espécie Leurolestes circunvagans. 2009. Disponível em: <http://seer.unipampa.edu.br/index.php/siepe/ article/view/5412>. Acesso em: 14 nov. 2016.

MURASHIGE, T.; SKOOG, F. A. A revised medium for a rapid growth and bioassays with tobacco tissues cultures. Plant Physiology, n. 1, p. 437-496, 1962.

RAMOS, D. M.; BORTOLUZZI, R. L. C.; MANTOVANI, A. Plantas medicinais de um remascente de floresta ombrófila mista altomontana, Urupema, Santa Catarina, Brasil. Revista Brasileira de Plantas Medicinais, v. 12, n. 3, p. 380-397, 2010. Disponível em: <http://www.scielo.br/scielo. php?script=sci_arttext\&pid=S1516-05722010000300016>. Acesso em: 14 jul. 2018.

SECCON, A.; ROSA, D. W.; FREITAS, R. A.; BIAVATTI, M. W.; CRECZYNSKI-PASA, T. B. Antioxidant activity and low cytotoxicity of extracts and isolated compounds from Araucaria angustifolia dead bark. Redox Report, v. 15, p. 234-242, 2010.

SILVEIRA, B. D.; HOSOKAWA, R. T.; NOGUEIRA, A. C.; WEBER, V. P. Atividade alelopática de Araucaria angustifolia (Bertol.) Kuntze na germinação e crescimento inicial de Lactuca sativa L. Ciência Florestal, v. 24, n. 1, p. 79-85, 2014.

SOUZA, M. D. O. Caracterização química, atividade antioxidante e antigenotóxica de extrato de brácteas de Araucária angustifolia (bert.) 0. Kuntze. 2013. Disponível em: <https:// repositorio.ucs.br/xmlui/bitstream/handle/11338/663/DissertacaoMarciaDenizeOliveiradeSouza. pdf? sequence $=1$ \&isAllowed $=\mathrm{y}>$. Acesso em: 19 nov. 2017.

TAIZ, L.; ZEIGER, E.; MOLLER, I. M.; MURPHY, A. Fisiologia vegetal. Porto Alegre: Artmed, 2017.

Received in: April 8, 2019

Accepted in: October 7, 2019 